10. Website planet (2019), "Unbounce", available at: https://www.websiteplanet.com/uk/landing-page-creators/unbounce/ (Accessed 14 November 2019).

11. Dealroom.co. (2018), Wijngaarde Y. Annual European Venture Capital Report 2017. Dealroom.co. 2018, February 18, available at: https://blog.dealroom.co/ annual-european-venture-capital-report-full-37-page-pdf-report (in USA), (Accessed 10 November 2019).

12. Wikipedia (2019), "Send Pulse", available at: https://uk.wikipedia.org/wiki/SendPulse, (Accessed 18 November 2019).

Іванова T.B.

канд. екон. наук, доцент ORCID ID: 0000-0001-9659-8681

Начіональний технічний університет Украӥни «Київський політехнічний інститут імені Ігоря Сікорського»

\title{
ІННОВАЦЙНА ДІЯЛЬНІСТЬ ПІДПРИЕМСТВ УКРАЇНИ ЯК ФАКТОР ПІДВИЩЕННЯ РІВНЯ КОНКУРЕНТОСПРОМОЖНОСТІ НА МІЖНАРОДНИХ РИНКАХ
}

\section{INNOVATIVE ACTIVITY OF UKRAINIAN ENTERPRISES AS A FACTOR OF INCREASING THE LEVEL OF COMPETITIVENESS IN INTERNATIONAL MARKETS}

\begin{abstract}
У дослідженні проведено аналіз інноваційної діяльності підприємств Украӥни задля розроблення рекомендащій щзодо підвищення рівня їх конкурентоспроможності на світових ринках. Проаналізовано показники інноваційного розвитку промислових вітчизняних підприємств у період з 2015 до 2019 рр. Виявлена тенденщія до зменшення кількості інноващійних підприємств на території України на фоні збільшення витрат на інновації на 3\%. Проте, у той же час, збільшується кількість інноваційної продукиії, щзо випускається. Виокремлено витрати на інновації підприємствами України за останні 5 років. Зроблено висновки, щэо більшість витрат мали тенденцію до збільшення, щэо вказує на позитивну динаміку. Також досліджено кількість промислових українських підприємств, які впроваджували інноващійну продукиію чи технологічні процеси за 2015-2019 рр. Прослідковується тенденція до зменшення, тобто варто звернути увагу керівництва підприємств на це питання для виявлення шляхів, щуо сприятимуть розвитку інновачійної діяльності. Проаналізовано джерела фінансування інновачійної діяльності з 2015 до 2019 р. В результаті аналізу визначено, що такими в основному були власні джерела підприємств (від 84\% до 97\%). Кількість коштів, щуо залучені від нерезидентів зменшилася на 28\%, отже треба виявити напрями, щзо дозволять зацікавити іноземних інвесторів. Проведено аналіз показників співробітництва інноваційних підприємств з партнерами із різних країн. Більшу частину інноваційної продукиії реалізують на ринку Украйни
\end{abstract}


(близько 57\%). Співпрачя з іншими державами поступово налагоджується, проте потрібно більш активно нарощувати иі темпи. На основі проведеного аналізу, запропоновано перелік заходів, що варто розробляти та впроваджувати на вітчизняних підприємствах для активізації інноваційної складової. Це дозволить також збільшити рівень конкурентоспроможності підприємств на вітчизняному та міжнародному ринках. Подальшими напрямами дослідження можуть бути питання щодо розроблення комплексної програми підтримки та розвитку інновачійної діяльності підприємств Украӥни на 2020-2030 рр.

Ключові слова: інноваційна діяльність, конкурентоспроможність, міжнародний ринок, промислові підприємства, фінансування

This study analyzed the innovative activities of Ukrainian enterprises in order to develop recommendations to increase their competitiveness in the world markets. The indicators of innovative development of industrial domestic enterprises in the period from 2015 to 2019 are analyzed. There was a tendency to reduce the number of innovative enterprises on the territory of Ukraine against the background of increasing the cost of innovations by 3\%. However, at the same time, the number of innovative products produced is increasing. The cost of innovation by Ukrainian enterprises over the last 5 years has been highlighted. It concluded that most of the costs tended to increase, indicating positive dynamics. The number of Ukrainian industrial enterprises that implemented innovative products or technological processes for 2015-2019 was also investigated. The downward trend is being followed, i.e. it is worth paying attention to the management of enterprises on this issue to identify ways that will contribute to the development of innovation activity. The sources of financing of innovation activity from 2015 to 2019 were analyzed as a result of the analysis, which determined that these mainly were their own sources of enterprises (from 84\% to 97\%). The number of funds raised from non-residents has decreased by $28 \%$, so it is necessary to identify areas that will allow interest to foreign investors. The analysis of indicators of cooperation of innovative enterprises with partners from different countries was conducted. Most of the innovative products are sold on the Ukrainian market (about 57\%). Cooperation with other countries is gradually adjusting, but it is necessary to increase these rates more actively. On the basis of the analysis, a list of measures is proposed, which should be developed and implemented at domestic enterprises to activate the innovative component. This will also increase the level of competitiveness of enterprises in domestic and international markets. Further directions of the study may be the development of a comprehensive program for supporting and developing innovative activities of enterprises of Ukraine for 2020-2030.

Keywords: innovation, competitiveness, international market, industrial enterprises, financing

Вступ. Кризові явища та глобальні зміни на міжнародному ринку спонукають підприємства до пошуку нових шляхів розвитку. Для збільшення присутності вітчизняних підприємств на міжнародних ринках, зокрема промислових, варто розробляти та впроваджувати заходи, що сприятимуть їх розвитку на основі інновацій. Що, у свою чергу, дозволять їм активно розвиватися та підвищувати рівень міжнародної конкурентоспроможності. 
Дослідженню питань щодо інноваційної діяльності підприємств України присвячено роботи наступних вітчизняних вчених: О. I. Амоша [1], Г. С. Волобуєв [2], В. Р. Волощук [3], О. В. Захарова та І. С. Барбанова [5], А. О. Касич [6], І. В. Колодяжна [7], М. В. Поплавський [8], Н. О. Пухальська [9], Ю. Сусіденко [10], І. О. Щебликіна [11], А. І. Яковлев [12] та інші. Однак, на підставі проведеного аналізу, виявлено, що недостатньо уваги приділено комплексному дослідженню інноваційної діяльності України за останній період, а також надання на основі нього рекомендацій, які сприятимуть збільшенню рівня конкурентоспроможності цих підприємств на міжнародному ринках.

Постановка завдання. Основною метою даного дослідження $\epsilon$ аналіз інноваційної діяльності вітчизняних підприємств та надання певних пропозицій щодо підвищення рівня міжнародної конкурентоспроможності. Для досягнення мети вирішуються наступні завдання: провести аналіз інноваційного розвитку промислових підприємств України; запропонувати заходи для підвищення рівня інноваційного розвитку промислових підприємств.

Методологія. Для досягнення поставленої мети були використані загальнонаукові та спеціальні методи: методи пізнання економічних явищ - при розгляді стану інноваційного розвитку підприємств; якісного та кількісного аналізу - при формуванні зведеної статистики щодо інновацій на вітчизняних підприємствах; логічного узагальнення та синтезу - при дослідженні стану інноваційної діяльності промислових підприємств України, для формулювання висновків. Інформаційною базою дослідження були аналітичні публікації, Інтернет-ресурси, публікації в наукових журналах.

Результати дослідження. Для визначення критичних аспектів та надання рекомендацій щодо підвищення рівня міжнародної конкурентоспроможності інноваційних підприємств України, варто розглянути динаміку їх основних показників діяльності за останні роки.

Показники інноваційної активності промислових підприємств України за 2015-2019 рр. наведено у табл. 1. 
Таблиця 1 - Основні показники інноваційного розвитку промислових підприємств України протягом 2015-2019 pp.

\begin{tabular}{|c|c|c|c|c|c|}
\hline Показники & 2015 & 2016 & 2017 & 2018 & 2019 \\
\hline $\begin{array}{ll}\text { Кількість } & \text { інноваційно- } \\
\text { активних } & \text { підприємств, } \\
\text { одиниць } & \\
\end{array}$ & 824 & 834 & 759 & 777 & 782 \\
\hline $\begin{array}{l}\text { у \% до загальної кількості } \\
\text { промислових підприємств }\end{array}$ & 17,3 & 18,9 & 16,2 & 16,4 & 15,8 \\
\hline $\begin{array}{l}\text { Витрати на інновації, млн. } \\
\text { грн. }\end{array}$ & 13813,7 & 23229,5 & 9117,5 & 12180,1 & 14220,9 \\
\hline $\begin{array}{cr}\text { У т.ч. \% } & \text { до загального } \\
\text { обсягу } & \text { реалізованої } \\
\text { промислової } & \text { продукції } \\
\text { (товарів, послуг) } & \\
\end{array}$ & 0,8 & 0,7 & 0,4 & 0,4 & 0,5 \\
\hline 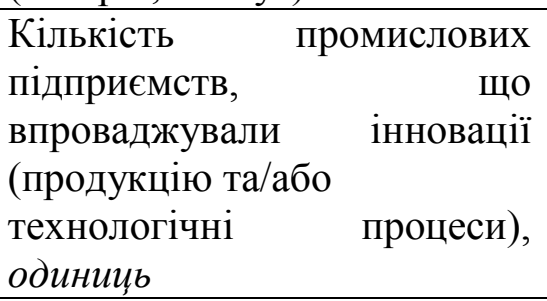 & 723 & 735 & 672 & 739 & 687 \\
\hline $\begin{array}{l}\text { у \% до загальної кількості } \\
\text { промислових підприємств }\end{array}$ & 15,2 & 16,6 & 14,3 & 15,6 & 13,8 \\
\hline $\begin{array}{lr}\text { Кількість } & \text { упроваджених } \\
\text { нових } & \text { технологічних } \\
\text { процесів, одиниць }\end{array}$ & 1217 & 3489 & 1831 & 2002 & 2318 \\
\hline $\begin{array}{l}\text { 3 них нових або суттєво } \\
\text { поліпшених } \\
\text { маловідходних, } \\
\text { ресурсозберігаючих, одиниць }\end{array}$ & 458 & 748 & 611 & 926 & 857 \\
\hline $\begin{array}{l}\text { Кількість у упроваджених } \\
\text { видів інноваційної продукції } \\
\text { (товарів, послуг), одиниць }\end{array}$ & 3136 & 4139 & 2387 & 3843 & 2148 \\
\hline $\begin{array}{l}\text { 3 них нових видів машин, } \\
\text { устатковання, приладів, } \\
\text { апаратів, одинищь }\end{array}$ & 966 & 1305 & 751 & 920 & 760 \\
\hline $\begin{array}{l}\text { Обсяг реалізованої } \\
\text { інноваційної продукції } \\
\text { (товарів, послуг), млн. грн. }\end{array}$ & 23050,1 & * & 17714,2 & 24861,1 & 34264,9 \\
\hline $\begin{array}{l}\text { \% до загального обсягу } \\
\text { реалізованої промислової } \\
\text { продукції (товарів, послуг), } \\
\text { млн. грн. }\end{array}$ & 1,4 & * & 0,7 & 0,8 & 1,3 \\
\hline
\end{tabular}

* - Розрахунок показника не здійснювався

Джерело: сформовано автором на основі [4]

На основі проведеного аналізу видно, що кількість інноваційноактивних підприємств в Україні з 2015 року до 2019 року знизилася на 5\%. Якщо розглядати витрати на інновації, то вони у період 2015-2019 
pp. збільшилися на 3\%. Хоча тенденція, яка була з 2015 року до 2016 року не зберіглася, але все ж відбулися позитивні зміни. Проте кількість промислових підприємств, що впроваджували інновації зазнала негативних змін, оскільки їх кількість з 2015 р. до 2019 р. зменшилася майже на $2 \%$. Щодо кількості впроваджених технологічних процесів на підприємствах України, то характерним є збільшення (на 90\%). Кількість упроваджених видів інноваційної продукції знизилася у період з 2015 р. до 2019 р. 33136 од. до 2148 од. (на 30\%). Можна спостерігати тенденцію до зменшення кількості інноваційно-активних підприємств в Україні, проте кількість впроваджених технологічних процесів поступово збільшується.

Наступним кроком варто проаналізувати витрати на інновації, що понесли підприємства України у період з 2015 до 2019 рр. (табл. 2). Важливо визначити на які саме напрями інноваційної діяльності треба звернути увагу керівництву підприємств для збільшення частки присутності на зовнішніх ринках.

Таблиця 2 - Витрати на інновації за напрямами інноваційної діяльності в Україні, 2015-2019 pр.

\begin{tabular}{|c|c|c|c|c|c|c|c|c|c|c|}
\hline Показники & 2015 & $\mathrm{y} \%$ & 2016 & $\mathrm{y} \%$ & 2017 & $\mathrm{y} \%$ & 2018 & $\mathrm{y} \%$ & 2019 & $\mathrm{y} \%$ \\
\hline Усього, млн. грн. & 13813,7 & 100,0 & 23229,5 & 100,0 & 9117,5 & 100,0 & 12180,1 & 100,0 & 14220,9 & 100,0 \\
\hline $\begin{array}{c}\text { внутрішні НДР, } \\
\text { млн. грн. }\end{array}$ & 1834,1 & 13,3 & 2063,8 & 8,9 & 1941,3 & 21,3 & 2706,1 & 22,2 & 2449,9 & 17,2 \\
\hline $\begin{array}{c}\text { зовнішні НДР, } \\
\text { млн. грн. }\end{array}$ & 205,4 & 1,5 & 394,1 & 1,7 & 228,5 & 2,5 & 502,6 & 4,1 & 469,0 & 3,3 \\
\hline $\begin{array}{c}\text { придбання } \\
\text { машин, } \\
\text { обладнання та } \\
\text { програмного } \\
\text { забезпечення, } \\
\text { млн. грн. }\end{array}$ & 11141,3 & 80,6 & 19829,0 & 85,3 & 5898,8 & 64,7 & 8291,3 & 68,1 & 10185,1 & 71,6 \\
\hline $\begin{array}{c}\text { придбання інших } \\
\text { зовнішніх знань, } \\
\text { млн. грн. }\end{array}$ & 84,9 & 0,6 & 64,2 & 0,3 & 21,8 & 0,2 & 46,1 & 0,4 & 37,5 & 2,6 \\
\hline інше, млн. грн. & 548,0 & 4,0 & 878,4 & 3,8 & 1027,1 & 11,3 & 633,9 & 5,2 & 1079,4 & 5,3 \\
\hline
\end{tabular}

Джерело: сформовано автором на основі [4]

Отже, в результаті аналізу визначено, що загальний показник витрат на інноваційну діяльність з 2015 р. до 2019 р. зріс майже на 3\%. Якщо брати до уваги показник витрат на внутрішні НДР, то з 2015 до 2019 pр. він зріс майже на 34\%. Показники зовнішніх НДР та придбання інших зовнішніх знань мали незначну тенденцію до збільшення, на $1,8 \%$ та $2 \%$ відповідно. Проте це вказує на позитивні 
зміни, оскільки підприємства мали змогу більше залучати внутрішні резерви для інноваційної діяльності. Стосовно показника, щодо придбання машин, обладнання та програмного забезпечення, то він зменшився майже на $10 \%$. Інші напрями витрат на інноваційну діяльність показали збільшення з 548,0 млн. грн. до 1079,9 млн. грн. (майже у 2 рази). Загалом проведений аналіз витрат на інноваційну діяльність вказує на позитивну тенденцію у сфері інноваційної діяльності.

Далі було проаналізовано кількість промислових підприємств України, що впроваджували інновації (табл. 3) у період з 2015 до 2019 pp.

Таблиця 3 - Кількість промислових підприємств України, що впроваджували інновації (продукцію та/або технологічні процеси), 2015-2019 pp.

\begin{tabular}{|l|c|c|c|c|c|}
\hline \multicolumn{1}{|c|}{ Показники } & 2015 & 2016 & 2017 & 2018 & 2019 \\
\hline Усього підприємств, од. & 723 & 735 & 672 & 739 & 687 \\
\hline $\begin{array}{l}\text { кількість упроваджених у виробництво нових } \\
\text { технологічних процесів, од. }\end{array}$ & 1217 & 3489 & 1831 & 2002 & 2318 \\
\hline $\begin{array}{l}\text { м них нових або суттєво поліпшених } \\
\text { маловідходних, ресурсозберігаючих } \\
\text { технологічних процесів, од. }\end{array}$ & 458 & 748 & 611 & 926 & 857 \\
\hline $\begin{array}{l}\text { кількість упроваджених видів інноваційної } \\
\text { продукції (товарів, послуг), од. }\end{array}$ & 3136 & 4139 & 2387 & 3843 & 2148 \\
\hline з них нових видів машин, обладнання, од. & 966 & 1305 & 751 & 920 & 760 \\
\hline
\end{tabular}

Джерело: сформовано автором на основі [4]

При аналізі кількості упроваджених у виробництво нових технологічних процесів на вітчизняних підприємствах у 2015-2019 pр. виявлено збільшення майже у 2 рази. А кількість упроваджених видів інноваційної продукції (товарів, послуг) у період з 2015 р. до 2019 р. зменшилася на 30\%. Варто провести більш детальне дослідження для виявлення резервів, що дозволять значно збільшити кількість інновацій на підприємствах.

Проведено аналіз джерел фінансування витрат на інновації (табл. 4). У результаті визначення джерел фінансування можливо розробити заходи щодо їх подальшого залучення у більшій мірі. 
Таблиця 4 - Витрати на інновації за джерелами фінансування, 20152019 pp.

\begin{tabular}{|l|c|c|c|c|c|c|c|c|c|c|c|}
\hline & \multicolumn{2}{|c|}{2015} & \multicolumn{2}{c|}{2016} & \multicolumn{2}{c|}{2017} & \multicolumn{2}{c|}{2018} & \multicolumn{2}{c|}{2019} \\
\cline { 2 - 12 } Показники & млн.грн. & у \% & млн.грн. & у \% & млн.грн. & у \% & млн.грн. & у \% & млн.грн. & у \% \\
\hline Усього & 13813,7 & 100,0 & 23229,5 & 100,0 & 9117,5 & 100,0 & 12180,1 & 100,0 & 14220,9 & 100,0 \\
\hline власні кошти & 13427,0 & 97,2 & 22036,0 & 94,9 & 7704,1 & 84,5 & 10742,0 & 88,2 & 12474,9 & 87,7 \\
\hline $\begin{array}{l}\text { державний } \\
\text { бюджет }\end{array}$ & 55,1 & 0,4 & 179,0 & 0,8 & 227,3 & 2,5 & 639,1 & 5,2 & 556,5 & 3,9 \\
\hline $\begin{array}{l}\text { місцеві } \\
\text { бюджети }\end{array}$ & 38,4 & 0,3 & 99,2 & 0,4 & 95,6 & 1,0 & 13,4 & 0,1 & 109,9 & 0,8 \\
\hline $\begin{array}{l}\text { інвестори- } \\
\text { резиденти }\end{array}$ & 74,3 & 0,5 & 134,4 & 0,6 & 273,1 & 3,0 & 109,7 & 0,9 & 72,3 & 0,5 \\
\hline $\begin{array}{l}\text { інвестори- } \\
\text { нерезиденти }\end{array}$ & 58,6 & 0,4 & 23,4 & 0,1 & 107,8 & 1,2 & 107,0 & 0,9 & 42,5 & 0,3 \\
\hline кредити & 113,7 & 0,8 & 626,0 & 2,7 & 594,4 & 6,5 & 473,9 & 3,9 & 853,2 & 6,0 \\
\hline інші джерела & 46,6 & 0,4 & 131,6 & 0,5 & 115,2 & 1,3 & 95,0 & 0,8 & 111,6 & 0,8 \\
\hline
\end{tabular}

Джерело: сформовано автором на основі [4]

У результаті аналізу виявлено, що кількість власних коштів, що залучалися для фінансування інноваційної діяльності підприємств України у 2015-2019 рр. знизилася майже на 7\%. Кількість коштів 3 державного та місцевого бюджетів збільшилися майже у 10 та 3 рази відповідно. Питома вага залучених коштів інвесторів-резидентів та нерезидентів має негативну динаміку (зменшилася на $3 \%$ та 28\% відповідно). Щодо залучення кредитів, то їх кількість збільшилася майже у 8 разів. Стосовно інших джерел фінансування, то вони збільшилися 32015 р. до 2019 р. 3 46,6 млн. грн. до 111,6 млн. грн. (у 2,5 рази). Можна стверджувати про негативну динаміку щодо фінансування інноваційної діяльності підприємств України.

Для аналізу інноваційної активності підприємств України було досліджено дані щодо співпраці за місцем розташування (табл. 5). 
Таблиця 5 - Частка кількості інноваційно активних підприємств України, залучених до інноваційного співробітництва за місцем розташування партнерів, 2012-2018 pр. у \% до загальної кількості інноваційно-активних підприємств

\begin{tabular}{|l|c|c|c|c|c|c|c|c|c|}
\hline & \multicolumn{3}{|c|}{ в Україні } & \multicolumn{3}{c|}{ країнами Свропи } & \multicolumn{3}{c|}{ іншими країнами } \\
\cline { 2 - 11 } & $2012-$ & $2014-$ & $2016-$ & $2012-$ & $2014-$ & $2016-$ & $2012-$ & $2014-$ & $2016-$ \\
Показник & 2014 & 2016 & 2018 & 2014 & 2016 & 2018 & 2014 & 2016 & 2018 \\
\hline Украӥна & 16,1 & 32,4 & 57,3 & 5,8 & 9,2 & 10,7 & 5,5 & 5,6 & 6,5 \\
\hline
\end{tabular}

Джерело: сформовано автором на основі [4]

Як видно, питома вага інноваційного співробітництва за місцем розташування партнерів у період 32012 р. до 2018 р. вказує на збільшення такого співробітництва у межах України, а саме з 16,1\% до $57,3 \%$ (на 41\%). 3 країнами Європи показник інноваційного співробітництва за 2012-2018 рр. теж має тенденцію до збільшення (майже на 5\%). 3 іншими країнами вітчизняні підприємства також покращили співпрацю, оскільки показник зріс на 1\%. 3 усіма партнерами українські інноваційні підприємства збільшили свою співпрацю, проте варто звернути увагу на розвиток міжнародного співробітництва.

На основі проведеного дослідження та аналізу, визначено, що для збільшення рівня міжнародної конкурентоспроможності українським інноваційним підприємствам варто звернути увагу на наступні пропозиції: розроблення та впровадження на рівні держави певних змін до законодавства, що сприятимуть розвитку інноваційних підприємств; участь у міжнародних проектах, що підтримують інноваційні розробки у країнах, що розвиваються; збільшення співпраці з ВНЗ для отримання кваліфікованих спеціалістів, а також до залучення проектів молодих науковців для розвитку інноваційної складової діяльності підприємств; залучення наукових установ до розроблення сучасних проектів щодо інноваційної продукції та процесів; вдосконалення існуючих норм та законів щодо захисту інтелектуальної власності.

Висновки. У результаті проведення аналізу отримано такі висновки: виконано детальний аналіз інноваційної діяльності промислових підприємств України за період з 2015 до 2019 року; запропоновано перелік заходів, що сприятимуть підвищенню рівня інноваційного розвитку та конкурентоспроможності підприємств на міжнародних ринках. При дослідженні виявлено, що кількість вітчизняних інноваційних підприємств зменшилася на $5 \%$, у той час витрати на інновації збільшилися на 3\%. Однак, збільшилася і кількість інноваційної продукції, що свідчить про позитивну тенденцію. Щодо витрат на інноваційну діяльність, то цей показник у період 2015-2019 
pp. зріс на 3\%. Також досліджено за 2015-2019 рр. Прослідковується тенденція до зменшення кількості промислових підприємств України, які впроваджують інноваційну продукцію та технологічні процеси. Стосовно джерел фінансування інноваційної діяльності з 2015 до 2019 p., то більша частина це власні джерела підприємств (близько 90\%). Також проведено аналіз показників співробітництва інноваційних підприємств 3 партнерами із України, Свропи та іншими країнами. Виявлено, що більша частина інноваційної продукції з 2012 р. до 2018 p. реалізована на вітчизняному ринку.

Наукова новизна полягає у дослідженні інноваційної активності промислових підприємств України та наданні пропозицій, що дозволять підвищити їх рівень інвестиційної привабливості та міжнародної конкурентоспроможності.

Отримані результати поглиблюють розуміння щодо інноваційної активності промислових підприємств України у період 2015-2019 pp., а також сприяють визначенню тенденцій, що склалися на даному етапі. Це дозволить 3 розумінням підійти до розроблення i наукового обгрунтування системи заходів щодо підвищення рівня інноваційної активності окремо взятого промислового підприємства.

Подальшого наукового дослідження та обгрунтування потребує комплексна програма підтримки та розвитку інноваційної діяльності підприємств України на 2020-2030 pp.

\section{Література:}

1. Амоша О. I. Інноваційний розвиток промислових підприємств у регіонах: проблеми та перспективи. Економіка України. 2017. № 3. С. 20-34.

2. Волобуєв Г. С. Сутність та передумови інноваційного розвитку підприємств. Економічний вісник Донбасу. 2016. № 3 (45). С. 213-217.

3. Волощук В. Р. Механізм активізації інноваційного розвитку. Інноваційна економіка. 2019. № 7-8. С. 27-33.

4. Державний комітет статистики України: сайт. URL: https://www.ukrstat.gov.ua (дата звернення 14.07.2020).

5. Захарова О. В., Барбанова I. С. Нормативне підгрунтя активізації інноваційного розвитку регіонів України. Економіка і організащія управління. 2019. Вип. 1. С. 53-63.

6. Касич А. О., Канунікова К. О. Інноваційна активність підприємств України: динаміка, проблеми та шляхи їх вирішення. Інвестищії: практика та досвід. 2016. № 22. С. 21-24.

7. Колодяжна I. В., Борблік К. Е. Джерела фінансування інноваційної діяльності підприємств України. Економіка і суспільство. 2017. Вип. 9. С. 448-453.

8. Поплавський М. В. Проблеми та перспективи розвитку інноваційної активності підприємств України на сучасному етапі. Збірник наукових пращь Харківського національного педагогічного університету імені Г.С. Сковороди «Економіка». 2017. № 17. C. 83-90. 
9. Пухальська Н. О., Гончаренко Л. М. Сучасний стан інноваційної діяльності вітчизняних промислових підприємств. Інфраструктура ринку. 2018. № 20. С. $113-118$.

10. Сусіденко Ю., Сіташ Т. Інноваційний розвиток підприємств: європейський досвід. Зовнішня торгівля: економіка, фінанси, право. 2016. № 3. С. 23-35.

11. Щебликіна I. О., Щебликіна 3. В., Баран О. М. Сучасний стан та проблеми інноваційного розвитку в системі стратегічного управління підприємств України. Вісник Запорізького національного університету. 2018. № 3 (39). С. 37 45.

12. Яковлев А. І. Аналіз стану інноваційної діяльності в Україні та шляхи його поліпшення. Наука та наукознавство. 2018. № 2 (100). С. 29-44.

\section{References:}

1. Amosha, O.I. (2017), “ Innovativee development of industrial enterprises in the regions: problems and perspects", Economy of Ukraine, vol. 3, pp. 20-34.

2. Volobujev, G.S. (2016), "Essence and pre-conditions of innovative development of enterprises", The Economic bulletin of Donbass, vol. 3 (45), pp. 213-217.

3. Voloshhuk, V.R. (2019), "Mechanism of activation of innovative development", Innovative economy, vol. 7-8, pp. 27-33.

4. State Statistics Service of Ukraine, available at: https://www.ukrstat.gov.ua (Accessed 14 July 2020).

5. Zaharova, O.V., Barbanova, I.S. (2019), "Regulatory basis for activization of innovative development of the Ukraine", Economics and organization of management, vol. 1, pp. 53-63.

6. Kasych, A.O., Kanunikova, K.O. (2016), "Innovative activity of Ukrainian companies: dynamics, problems and solutions", Investycii': praktyka ta dosvid, vol. 22, pp. 21-24.

7. Kolodjazhna, I.V., Borblik, K.E. (2017), " Sources of financing of innovative activity of enterprises of Ukraine", Ekonomika i suspil'stvo, vol. 9, pp. 448-453.

8. Poplavs'kyj, M.V. (2017), " Problems and prospects of development of innovative activity of the enterprises of Ukraine at the present stage", Zbirnyk naukovyh prac' Harkivs'kogo nacional'nogo pedagogichnogo universytetu imeni G.S. Skovorody «Ekonomika», vol. 17, pp. 83-90.

9. Puhal's'ka, N.O., Goncharenko, L. M. (2018), "The modern status of innovation activity of domestic industrial enterprises", Market Infrastructure, vol. 20, pp. 113118.

10. Susidenko, Ju., Sitash, T. (2016), “ Innovative development of enterprises: European experience", Foreign trade: economics, finance, law, vol. 3, pp. 23-35.

11. Shheblykina, I.O., Shheblykina, Z.V., Baran, O.M. (2018), "Modern state and problems of innovative development in the system of strategic management of enterprises of Ukraine", Bulletin of Zaporizhzhia National University. Economic Sciences, vol. 3 (39), pp. 37-45.

12. Jakovlev, A.I. (2018), "Analysis of the innovation performance in Ukraine and ways for its enhancement”, Science And Science of Science, vol. 2 (100), pp. 29-44. 